\author{
PaWel Gata ${ }^{1}$
}

\title{
Problematyka bioróżnorodności w nowym PROW na lata 2014-2020
}

\section{Zagadnienia wstępne}

Historia człowieka na Ziemi liczy sobie 200 tysięcy lat. To stosunkowo krótki fragment 4,6-miliardowej historii planety. Człowiek, podobnie jak inne organizmy żywe, od swojego pojawienia się na Ziemi przekształcał otaczające go środowisko naturalne, dostosowując je do swoich potrzeb. Jednak tym, co wyróżnia człowieka spośród innych gatunków zamieszkujących Ziemię, jest skala dokonanych przez niego zmian środowiska naturalnego. ${ }^{2}$ To człowiek zasiedlił niemal cały obszar Ziemi, rozwinął przemysł i rolnictwo, przeciął planetę szeregiem dróg i autostrad. Działalność ta odmieniła oblicze naszej planety. ${ }^{3}$

Jednym z efektów ekspansji człowieka na Ziemi jest ogromny wzrost tempa wymierania gatunków. Wymieranie gatunków, co do zasady, jest procesem naturalnym, do którego dochodzi na skutek nieustannych zmian zachodzących w środowisku. Wymieranie jest procesem, podczas którego słabe, nie potrafiące się przystosować gatunki, giną. Jednak obecnie człowiek tak szybko i na tak wielką skalę przekształca przyrodę, że tempo wymierania gatunków stało się katastrofalne. ${ }^{4}$ Co najmniej 20 gatunków zwierząt i roślin ginie każdego dnia w wyniku zanieczyszczeń i przekształceń w ich naturalnym środowisku. Szacuje się, że w ciągu najbliższych 30 lat tempo to wzrośnie do ponad 100 gatunków dziennie. ${ }^{5}$ Nie ulega już żadnej wątpliwości, że wskaźniki wymierania gatunków są w chwili obecnej niezwykle wysokie. Szacuje się, że głównie w wyniku działalności człowieka tempo wymierania gatunków jest obecnie od 100 do 1000 razy szybsze niż w warunkach naturalnych: według FAO, 60\% światowych ekosystemów uległo degradacji lub jest nie-

N.S. Sodhi, P. Ehrlich, Conservation biology for all, New York 2010, s. 1-2.

S. Kozłowski, Przyszłość ekorozwoju, Lublin 2007, s. 32-33.

M. Soule, G. Orians, Conservation biology. Research priorities for the next decade, society for conservation biology, Washington 2001, s. 6.

5 Millennium Ecosystem Assessment, 2005. Ecosystems and Human Well-being: Synthesis., Washington, DC, s. $36-37$. 
właściwie wykorzystywanych; 75\% stad ryb jest nadmiernie eksploatowanych lub w znacznym stopniu wyczerpanych, a od 1990 r. na całym świecie utracono $75 \%$ różnorodności genetycznej upraw rolnych. Każdego roku wycina się około $13 \mathrm{mln}$ hektarów lasów tropikalnych, a 20\% tropikalnych raf koralowych na świecie już zniknęło, natomiast $95 \%$ tych raf narażonych zostanie na ryzyko zniszczenia lub znacznego uszkodzenia do 2050 r., jeżeli nie powstrzyma się zmiany klimatu. ${ }^{6}$

Tak szybki proces wymierania gatunków prowadzi zatem do znaczącego ograniczenia bioróżnorodności. Tymczasem jej ochrona jest konieczna z najbardziej elementarnych przyczyn:

- dla zachowania mechanizmów działania żywej przyrody;

- dla zachowania zdolności przyrody do przetrwania zmian środowiska;

- dla zapobieżenia utracie wartości przyrodniczych, jeszcze nieodkrytych i niewykorzystanych, które mogą być podstawą rozwoju i gwarancją przeżycia przyszłych pokoleń.

Problem konieczności ochrony bioróżnorodności został dostrzeżony przez ludzi późno, ${ }^{7}$ a na jego regulację prawną trzeba było czekać jeszcze dłużej. Dopiero podczas Konferencji Narodów Zjednoczonych na temat Środowiska i Rozwoju (tzw. „Szczytu Ziemi”) w Rio de Janeiro, 5 czerwca 1992 r. społeczność międzynarodowa powołała do życia Konwencję o różnorodności biologicznej. ${ }^{8}$ Konwencja ta wskazała trzy zasadnicze ${ }^{9}$ cele:

- ochronę różnorodności biologicznej,

- zrównoważone użytkowanie jej elementów;

- uczciwy i sprawiedliwy podział korzyści wynikających z wykorzystania zasobów genetycznych. ${ }^{10}$

L. Burke, K. Reytar, M. Spalding, A. Perry, Raport „Reefs at Risk Revisted”, Światowy Instytut Zasobów (World Resources Institute), Washington DC, 2011, s. 5.

7 W literaturze pojęcie „bioróżnorodność” po raz pierwszy użył R. Dalesman: A different kind of country, 1968 r.

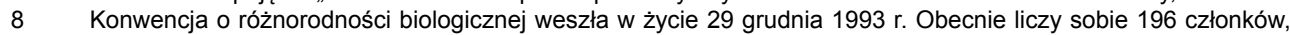
w tym Polskę (która ratyfikowała Konwencję w 1996 r. - tekst jedn. Dz.U. z 2002 r. Nr 184, poz. 1532) oraz Unię Europejską (która przyjęła Konwencję Decyzją Rady (EWG) z dnia 25 października 1993 r. - Dz.U. L 309 z dnia 13 grudnia 1993 r., s. 1-20). Podczas Szczytu Ziemi wraz z Konwencją o różnorodności biologicznej przyjęto także: Ramową Konwencję Narodów Zjednoczonych w sprawie zmian klimatu (Konwencja Klimatyczna), ratyfikowaną przez Polskę w 1994 r. (Dz.U. z 1996 r. Nr 53, poz. 238) oraz Konwencję Narodów Zjednoczonych w sprawie zwalczania pustynnienia w państwach dotkniętych poważnymi suszami i/lub pustynnieniem, zwłaszcza w Afryce (Dz.U. z 2002 r. Nr 185, poz. 1538). Do Konwencji o różnorodności biologicznej zostały przyjęte dwa protokoły, uszczegóławiające jej postanowienia: w odniesieniu do transgranicznego przemieszczania żywych zmodyfikowanych genetycznie organizmów - Protokół Kartageński o bezpieczeństwie biologicznym do Konwencji o różnorodności biologicznej - przyjęty w dniu 29 stycznia 2000 r. w Montrealu, ratyfikowany przez Polskę w 2003 r. (Dz.U. z 2004 r. Nr 216, poz. 2201) oraz w odniesieniu do dzielenia się korzyściami z wykorzystania zasobów genetycznych - Protokół z Nagoi do Konwencji o różnorodności biologicznej dotyczący dostępu do zasobów genetycznych oraz uczciwego i sprawiedliwego podziału korzyści wynikających z ich wykorzystania, przyjęty w dniu 29 października 2010 r. w Nagoi, podpisany przez Polskę w dniu 20 września 2011 r. 
Konwencja zdefiniowała także samo pojęcie „różnorodność biologiczna” wskazując, że oznacza ono zróżnicowanie wszystkich żywych organizmów występujących na Ziemi w ekosystemach lądowych, morskich i słodkowodnych oraz w zespołach ekologicznych, których są częścią. Dotyczy ona różnorodności w obrębie gatunku, pomiędzy gatunkami oraz różnorodności ekosystemów. ${ }^{11}$

W zakresie realizacji wskazanych wyżej celów, Konwencja nałożyła na swoich sygnatariuszy szereg obowiązków. ${ }^{12}$ Część z tych zobowiązań wiąże się z koniecznością wypracowania określonej polityki działania, zakreślenia jej planów oraz wdrożenia odpowiedniej regulacji prawnej. Spośród takich zobowiązań konwencyjnych warto wymienić zobowiązanie do:

- opracowania krajowych strategii, planów lub programów dotyczących ochrony i zrównoważonego użytkowania różnorodności biologicznej bądź dostosowania w tym celu istniejących strategii, planów lub programów, które odzwierciedlają działania przewidziane Konwencją,

- włączenia, w miarę możliwości i potrzeby, problematyki ochrony i zrównoważonego użytkowania różnorodności biologicznej do odpowiednich sektorowych i międzysektorowych planów, programów i polityk,

- ustanowienia systemu obszarów chronionych lub obszarów, na których muszą być podjęte specjalne działania w celu ochrony różnorodności biologicznej,

- objęcia odpowiednimi regulacjami i zarządzania zasobami biologicznymi ważnymi dla zachowania różnorodności biologicznej zarówno na obszarach objętych ochroną, jak i poza ich granicami, mając na względzie zapewnienie ochrony tych zasobów i zrównoważone ich użytkowanie,

- ustanowienia lub utrzymania środków umożliwiających regulowanie, zarządzanie lub kontrolę ryzyka związanego z użytkowaniem i uwalnianiem żywych, zmodyfikowanych biotechnologicznie organizmów, które mogą negatywnie oddziaływać na środowisko i wpływać na ochronę oraz zrównoważone użytkowanie różnorodności biologicznej, biorąc także pod uwagę zagrożenia dla ludzkiego zdrowia,

- opracowania lub utrzymania niezbędnych regulacji prawnych i/lub innych przepisów dotyczących ochrony zagrożonych gatunków i populacji,

- włączenia problematyki ochrony i zrównoważonego użytkowania zasobów biologicznych w proces podejmowania decyzji na szczeblu krajowym, 
- zachęcania do współpracy pomiędzy swoimi organami rządowymi a swoim sektorem prywatnym w opracowywaniu metod sprzyjających zrównoważonemu użytkowaniu zasobów biologicznych,

- wprowadzenia odpowiednich uregulowań dla zapewnienia, że środowiskowe konsekwencje programów i polityk danego państwa członkowskiego, które mogą mieć znacząco negatywne oddziaływanie na różnorodność biologiczną, są w sposób należyty brane pod uwagę.

Powyższe zobowiązania winny zatem znaleźć swoje odbicie, w przypadku Polski, tak w przepisach prawa krajowego, jak i prawa Unii Europejskiej.

\section{Problematyka ochrony różnorodności biologicznej w prawie krajowym i wspólnotowym}

Zobowiązania Polski oraz Unii Europejskiej, jako sygnatariuszy Konwencji o różnorodności biologicznej, stały się podstawą do przyjęcia, zarówno na szczeblu krajowym jak i wspólnotowym, szeregu regulacji: tak politycznych, jak i prawnych.

Podstawowym dokumentem programowym Unii Europejskiej dotyczącym kwestii ochrony bioróżnorodności jest obecnie Komunikat Komisji do Parlamentu Europejskiego, Rady, Europejskiego Komitetu Ekonomiczno-Społecznego i Komitetu Regionów Nasze ubezpieczenie na życie i nasz kapitał naturalny - unijna strategia ochrony różnorodności biologicznej na okres do 2020 r. $^{13}$

Dokument ten zakłada, że do roku 2020 Unia Europejska zrealizuje sześć podstawowych celów w zakresie ochrony różnorodności biologicznej. Cele te obejmują:

- Pełne wdrożenie dyrektywy ptasiej oraz siedliskowej;

- Utrzymanie i odbudowę ekosystemów i ich funkcji;

- Zwiększenie wkładu rolnictwa i leśnictwa w utrzymanie i wzmocnienie różnorodności biologicznej;

- Zapewnienie zrównoważonego wykorzystania zasobów rybnych;

- Zwalczanie inwazyjnych gatunków obcych;

- Pomoc na rzecz zapobiegania utracie światowej różnorodności biologicznej.

Zważywszy na temat niniejszego opracowania szczególne znaczenie ma trzeci z przedstawionych wyżej celów, tj. zwiększenie wkładu rolnictwa w utrzymanie i wzmocnienie różnorodności biologicznej. Problematyce tej poświęcona będzie osobna część niniejszego opracowania. 
Polityka ochrony bioróżnorodności na szczeblu Unii Europejskiej realizowana jest poprzez szereg uregulowań prawnych. Na regulację taką składają się dyrektywy podlegające implementacji do wewnętrznych porządków prawnych krajów członkowskich UE, m.in.:

- Dyrektywa Parlamentu Europejskiego i Rady nr 2009/147/WE z dnia 30 listopada 2009 r. w sprawie ochrony dzikiego ptactwa, ${ }^{14}$

- Dyrektywa Rady Nr 92/43/EWG z dnia 21 maja 1992 r. w sprawie ochrony siedlisk przyrodniczych oraz dzikiej fauny i flory (dyrektywa siedliskowa), ${ }^{15}$

- Dyrektywa Parlamentu Europejskiego i Rady nr 2001/18/WE z dnia 12 marca 2001 r. w sprawie zamierzonego uwalniania do środowiska organizmów zmodyfikowanych genetycznie i uchylająca dyrektywę Rady nr 90/220/ EWG, ${ }^{16}$

- Dyrektywa Parlamentu Europejskiego i Rady nr 2000/60/WE z dnia 23 października 2000 r. ustanawiająca ramy wspólnotowego działania w dziedzinie polityki wodnej (ramowa dyrektywa wodna), ${ }^{17}$

- Dyrektywa Parlamentu Europejskiego i Rady nr 2004/35/WE z dnia 21 kwietnia 2004 r. w sprawie odpowiedzialności za środowisko w odniesieniu do zapobiegania i zaradzania szkodom wyrządzonym środowisku naturalnemu, ${ }^{18}$

- Dyrektywa Parlamentu Europejskiego i Rady nr 2008/56/WE z dnia 17 czerwca 2008 r. ustanawiająca ramy działań Wspólnoty w dziedzinie polityki środowiska morskiego (dyrektywa ramowa w sprawie strategii morskiej). ${ }^{19}$

- Problematyka ochrony bioróżnorodności znalazła także swoje odzwierciedlenie w przepisach nowego pakietu legislacyjnego Wspólnej Polityki Rolnej na lata 2014-2020, w szczególności w uregulowaniach:

- Rozporządzenia Parlamentu Europejskiego i Rady (UE) nr 1305/2013 z dnia 17 grudnia 2013 r. w sprawie wsparcia rozwoju obszarów wiejskich przez Europejski Fundusz Rolny na rzecz Rozwoju Obszarów Wiejskich (EFRROW) i uchylające rozporządzenie Rady (WE) nr 1698/2005, ${ }^{20}$

- Rozporządzenia Parlamentu Europejskiego i Rady (UE) nr 1306/2013 z dnia 17 grudnia 2013 w sprawie finansowania wspólnej polityki rolnej, zarządzania nią i monitorowania jej oraz uchylające rozporządzenia Rady (EWG) 
nr 352/78, (WE) nr 165/94, (WE) nr 2799/98, (WE) nr 814/2000, (WE) nr 1290/2005 i (WE) $\mathrm{nr} 485 / 2008,{ }^{21}$

- Rozporządzenia Parlamentu Europejskiego i Rady (UE) nr 1307/2013 z dnia 17 grudnia 2013 r. ustanawiające przepisy dotyczące płatności bezpośrednich dla rolników na podstawie systemów wsparcia w ramach wspólnej polityki rolnej oraz uchylające rozporządzenie Rady (WE) nr 637/2008 i rozporządzenie Rady (WE) nr 73/2009, ${ }^{22}$

- Rozporządzenia Parlamentu Europejskiego i Rady (UE) nr 1308/2013 z dnia 17 grudnia 2013 r. ustanawiające wspólną organizację rynków produktów rolnych oraz uchylające rozporządzenia Rady (EWG) nr 922/72, (EWG) nr 234/79, (WE) nr 1037/2001 i (WE) nr 1234/2007. ${ }^{23}$

Zważywszy na zakres niniejszego opracowania, w jego dalszej części rozważania koncentrować się będą wokół kwestii ochrony różnorodności biologicznej w ramach regulacji prawnych UE dotyczących rozwoju obszarów wiejskich.

Podobnie jak ma to miejsce w ramach Unii Europejskiej, również w Polsce, na szczeblu krajowym funkcjonuje szereg dokumentów programowych, które swoim zakresem obejmują także zagadnienia ochrony różnorodności biologicznej. Wśród dokumentów takich wskazać można:

- Długookresową Strategię Rozwoju Kraju - Polska 2030. Trzecia Fala Nowoczesności, ${ }^{24}$

- Średniookresową Strategię Rozwoju Kraju - Strategia Rozwoju Kraju $2020,,^{25}$

- Koncepcję Przestrzennego Zagospodarowania Kraju 2030, ${ }^{26}$

- Strategię Rozwoju Transportu do 2020 roku (z perspektywą do 2030 roku), ${ }^{27}$

- Strategię zrównoważonego rozwoju wsi, rolnictwa i rybactwa na lata 2012$2020,{ }^{28}$

- Krajową Strategię Rozwoju Regionalnego 2010-2020: Regiony, Miasta, Obszary wiejskie, ${ }^{29}$

- Strategię Bezpieczeństwo Energetyczne i Środowisko - perspektywa do 2020 r. (BEiŚ), ${ }^{30}$ 
- Program Rozwoju Obszarów Wiejskich na lata 2014-2020.

Również w tym przypadku wskazane wyżej dokumenty o charakterze programowym realizowane są za pośrednictwem regulacji prawnych. Polska, krajowa regulacja prawna dotycząca ochrony różnorodności biologicznej zawarta jest m.in. w przepisach:

- Ustawy z dnia 16 kwietnia 2004 r. o ochronie przyrody ${ }^{31}$ wraz z jej aktami wykonawczymi, ${ }^{32}$

- Ustawy z dnia 22 czerwca 2001 r. o mikroorganizmach i organizmach genetycznie zmodyfikowanych, ${ }^{33}$

- Ustawy z dnia 20 lutego 2015 r. o wspieraniu rozwoju obszarów wiejskich z udziałem środków Europejskiego Funduszu Rolnego na rzecz Rozwoju Obszarów Wiejskich w ramach Programu Rozwoju Obszarów Wiejskich na lata 2014-2020 $0^{34}$ wraz z jej aktami wykonawczymi. ${ }^{35}$

Również w tym przypadku dalsza część opracowania koncentrować się będzie na zagadnieniach związanych z ochroną różnorodności biologicznej w ramach regulacji prawnych dotyczących rozwoju obszarów wiejskich.

\section{Różnorodność biologiczna w nowym PROW na lata 2014-2020}

Przede wszystkim podkreślić należy, że Wspólna Polityka Rolna UE, w zakresie wsparcia rozwoju obszarów wiejskich w latach 2014-2020, zorientowana jest na sześć priorytetów UE obejmujących:

- wspieranie transferu wiedzy i innowacji w rolnictwie, leśnictwie i na obszarach wiejskich,

- zwiększenie rentowności gospodarstw i konkurencyjności wszystkich rodzajów rolnictwa we wszystkich regionach oraz promowanie innowacyjnych technologii w gospodarstwach i zrównoważonego zarządzania lasami,

Tekst jedn. Dz.U. z 2013 r. poz. 627 ze zm.

Np. Rozporządzenie Ministra Środowiska z dnia 12 stycznia 2011 r. w sprawie obszarów specjalnej ochrony ptaków (Dz.U. z 2011 r. Nr 25, poz. 133 ze zm.); Rozporządzenie Ministra Środowiska z dnia 09 października 2014 r. w sprawie ochrony gatunkowej roślin (Dz.U. z 2014 r. poz. 1409); Rozporządzenie Ministra Środowiska z dnia 06 października 2014 r. w sprawie ochrony gatunkowej zwierząt (Dz.U. z 2014 r. poz. 1348).

Tekst jedn. Dz.U. z 2007 r. Nr 36, poz. 233 ze zm.

Dz.U. z 2015 r. poz. 349.

Np. Rozporządzenie Ministra Rolnictwa i Rozwoju Wsi z dnia 13 marca 2015 r. w sprawie szczegółowych warunków i trybu przyznawania pomocy finansowej w ramach działania „Rolnictwo ekologiczne” objętego Programem Rozwoju Obszarów Wiejskich na lata 2014-2020 (Dz.U. z 2015 r. poz. 370); Rozporządzenie Ministra Rolnictwa i Rozwoju Wsi z dnia 13 marca 2015 r. w sprawie szczegółowych warunków i trybu przyznawania pomocy finansowej w ramach działania „Płatność dla obszarów z ograniczeniami naturalnymi lub innymi szczególnymi ograniczeniami” objętego Programem Rozwoju Obszarów Wiejskich na lata 2014-2020 (Dz.U. z 2015 r. poz. 364). 
- wspieranie organizacji łańcucha dostaw żywności, w tym przetwarzania i wprowadzania do obrotu produktów rolnych, promowanie dobrostanu zwierząt i zarządzania ryzykiem w rolnictwie,

- odtwarzanie, ochronę i wzbogacanie ekosystemów powiązanych z rolnictwem i leśnictwem,

- wspieranie efektywnego gospodarowania zasobami i przechodzenia na gospodarkę niskoemisyjną i odporną na zmianę klimatu w sektorach rolnym, spożywczym i leśnym,

- wspieranie włączenia społecznego, ograniczania ubóstwa i rozwoju gospodarczego na obszarach wiejskich. ${ }^{36}$

Warto zauważyć, że żaden z ww. celów strategicznych UE nie odnosi się wprost do potrzeby ochrony różnorodności biologicznej. Jednak uszczegóławiając te priorytety, prawodawca unijny wyznaczył cele szczegółowe związane z ochroną bioróżnorodności.

W ramach priorytetu czwartego (odtwarzanie, ochrona i wzbogacanie ekosystemów powiązanych z rolnictwem i leśnictwem), ustanowiono cel szczegółowy obejmujący odtwarzanie, ochronę i wzbogacanie różnorodności biologicznej, w tym na obszarach Natura 2000 i obszarach z ograniczeniami naturalnymi lub innymi szczególnymi ograniczeniami, oraz rolnictwa o wysokiej wartości przyrodniczej, a także stanu europejskich krajobrazów.

Dodatkowo prawodawca unijny w preambule Rozporządzenia 1305/2013 podniósł, że:

Państwa członkowskie powinny mieć możliwość włączania do swoich programów rozwoju obszarów wiejskich podprogramy tematyczne ukierunkowane na specyficzne potrzeby obszarów mających dla nich szczególne znaczenie. Podprogramy tematyczne powinny dotyczyć między innymi młodych rolników, małych gospodarstw, obszarów górskich, tworzenia krótkich łańcuchów dostaw, kobiet na obszarach wiejskich, łagodzenia skutków zmiany klimatu i przystosowania się do niej oraz różnorodności biologicznej.

Regulacja ta stanowi novum w ramach europejskiej regulacji dotyczącej rozwoju obszarów wiejskich. Założenia określone w preambule Rozporządzenia nr 1305/2013 doprecyzowuje jego art. 7 (w zw. z załącznikiem IV) wskazując, że orientacyjny wykaz działań i rodzajów operacji, w ramach których możliwe jest ustanowienie podprogramu tematycznego w zakresie łagodzenia skutków zmiany klimatu i przystosowania się do niej oraz różnorodności biologicznej może obejmować: wsparcia rozwoju obszarów wiejskich przez Europejski Fundusz Rolny na rzecz Rozwoju Obszarów Wiejskich (EFRROW) i uchylające rozporządzenie Rady (WE) nr 1698/2005. 
- transfer wiedzy i działalność informacyjną;

- usługi doradcze, usługi z zakresu zarządzania gospodarstwem i zastępstw;

- inwestycje w środki trwałe;

- przywracanie potencjału produkcji rolnej zniszczonego w wyniku klęsk żywiołowych oraz wprowadzanie odpowiednich środków zapobiegawczych;

- podstawowe usługi i odnowę wsi na obszarach wiejskich;

- inwestycje w rozwój obszarów leśnych i zwiększenie rentowności lasów;

- działania rolnośrodowiskowo-klimatyczne;

- rolnictwo ekologiczne;

- płatności z tytułu programu Natura 2000 i ramowej dyrektywy wodnej;

- płatności dla obszarów z ograniczeniami naturalnymi i innymi szczególnymi ograniczeniami (różnorodność biologiczna);

- usługi rolnośrodowiskowe i klimatyczne oraz ochrona lasów;

- współpraca;

- zarządzanie ryzykiem.

Uznać zatem należy, że przepisy Rozporządzenia nr 1305/2013 dają podstawę prawną dla krajowych Programów Rozwojów Obszarów Wiejskich dla określenia działań wspierających ochronę bioróżnorodności.

Konieczna jest zatem analiza przepisów ustawy z dnia 20 lutego 2015 r. o wspieraniu rozwoju obszarów wiejskich z udziałem środków Europejskiego Funduszu Rolnego na rzecz Rozwoju Obszarów Wiejskich w ramach Programu Rozwoju Obszarów Wiejskich na lata 2014-2020 (dalej: u.w.r.o.w.) oraz jej aktów wykonawczych celem określenia zakresu wsparcia dla działań dotyczących różnorodności biologicznej na terytorium RP. Zwłaszcza że Program Rozwoju Obszarów Wiejskich na lata 2014-2020 w swojej części analitycznej poświęca dużo miejsca problemowi ochrony bioróżnorodności w Polsce. Najistotniejszym elementem tej analizy wydaje się konstatacja, że Polska jest krajem, któremu w stosunku do innych krajów Unii Europejskiej udało się zachować bioróżnorodność w wysokim stopniu. Jest to następstwem: funkcjonowania w kraju tradycyjnej gospodarki rolnej, szczególnie w rejonach o mozaikowatej strukturze agrarnej, wysokiego udziału trwałych użytków rolnych oraz obszarów półnaturalnych w tym mokradłowych, których duża część położona jest na obszarach Natura 2000, a także występowania na znacznych obszarach kraju zróżnicowanych przyrodniczo lasów. Należy podkreślić, że autorzy PROW wskazują na różnorodność biologiczną jako mocną stronę polskiego rolnictwa. 
Analiza przepisów art. 3 u.w.r.o.w. pozwala wskazać trzy działania o szczególnym znaczeniu w procesie ochrony i utrzymania bioróżnorodności w Polsce. Są to kolejno:

- działanie rolnośrodowiskowo-klimatyczne (art. 3 ust. 1 pkt 10) ustawy);

- rolnictwo ekologiczne (art. 3 ust. 1 pkt 11) ustawy); oraz

- płatności dla obszarów z ograniczeniami naturalnymi lub innymi szczególnymi ograniczeniami (art. 3 ust. 1 pkt 12) ustawy).

Szczegółowe warunki i tryb przyznawania, wypłaty oraz zwrotu pomocy finansowej w ramach działania „Działanie rolnośrodowiskowo-klimatyczne” określa Rozporządzenie Ministra Rolnictwa i Rozwoju Wsi z dnia 18 marca 2015 r. w sprawie szczegółowych warunków i trybu przyznawania pomocy finansowej w ramach działania „Działanie rolnośrodowiskowo-klimatyczne” objętego Programem Rozwoju Obszarów Wiejskich na lata 2014-2020. W oparciu o te przepisy rolnik (lub zarządca) może ubiegać się o przyznanie płatności rolnośrodowiskowo-klimatycznej w ramach następujących pakietów:

- rolnictwo zrównoważone,

- ochrona gleb i wód,

- zachowanie sadów tradycyjnych odmian drzew owocowych,

- cenne siedliska i zagrożone gatunki ptaków na obszarach Natura 2000,

- cenne siedliska poza obszarami Natura 2000,

- zachowanie zagrożonych zasobów genetycznych roślin w rolnictwie,

- zachowanie zagrożonych zasobów genetycznych zwierząt w rolnictwie.

W ramach działania „Rolnictwo ekologiczne” szczegółowe warunki i tryb przyznawania, wypłaty oraz zwrotu pomocy finansowej określa Rozporządzenia Ministra Rolnictwa i Rozwoju Wsi z dnia 13 marca 2015 r. w sprawie szczegółowych warunków i trybu przyznawania pomocy finansowej w ramach działania „Rolnictwo ekologiczne" objętego Programem Rozwoju Obszarów Wiejskich na lata 20142020. Na podstawie tych regulacji płatność ekologiczna może być przyznana rolnikowi realizującemu działania obejmujące następujące pakiety:

- uprawy rolnicze w okresie konwersji, ${ }^{37}$

- uprawy warzywne w okresie konwersji,

- uprawy zielarskie w okresie konwersji,

37 Pojęcie „konwersji” definiuje art. 2 ppkt h) Rozporządzenia Rady (WE) nr 834/2007 z dnia 28 czerwca 2007 r. w sprawie produkcji ekologicznej i znakowania produktów ekologicznych i uchylające rozporządzenie (EWG) nr 2092/91 (Dz.Urz. UE L 189 z dnia 20 lipca 2007 r., s.1), wskazując, że „konwersja” oznacza przejście z rolnictwa nieekologicznego na rolnictwo ekologiczne w danym okresie, w trakcie którego stosowano przepisy dotyczące produkcji ekologicznej. 
- uprawy sadownicze w okresie konwersji,

- uprawy paszowe na gruntach ornych w okresie konwersji,

- trwałe użytki zielone w okresie konwersji,

- uprawy rolnicze po okresie konwersji,

- uprawy warzywne po okresie konwersji,

- uprawy zielarskie po okresie konwersji,

- uprawy sadownicze po okresie konwersji,

- uprawy paszowe na gruntach ornych po okresie konwersji,

- trwałe użytki zielone po okresie konwersji.

Trzecią grupę przepisów dotyczących wsparcia różnorodności biologicznej w ramach PROW 2014-2020 stanowią regulacje Rozporządzenie Ministra Rolnictwa i Rozwoju Wsi z dnia 13 marca 2015 r. w sprawie szczegółowych warunków i trybu przyznawania pomocy finansowej w ramach działania „Płatności dla obszarów z ograniczeniami naturalnymi lub innymi szczególnymi ograniczeniami” objętego Programem Rozwoju Obszarów Wiejskich na lata 2014-2020. W tym przypadku rolnik otrzymuje płatność dla obszarów z ograniczeniami naturalnymi lub innymi szczególnymi ograniczeniami (płatność ONW) bez konieczności realizowania określonego programu. Jest to płatność do przyznawania do użytków rolnych, położonych na obszarach górskich lub na innych obszarach charakteryzujących się szczególnymi ograniczeniami naturalnymi lub innymi szczególnymi ograniczeniami, zwanymi obszarami ONW, na których jest prowadzona działalność rolnicza. Wysokość przyznawanej płatności uzależniona jest od miejsca położenia użytków rolnych.

\section{Konkluzje}

Niewątpliwie regulacje prawne, tak wspólnotowe, jak i krajowe dotyczące wsparcia rozwoju obszarów wiejskich zawierają rozwiązania mające na celu ochronę różnorodności biologicznej. Wydaje się także, że rozwiązania te zmierzają w kierunku ukształtowania spójnego systemu wspierania bioróżnorodności. Jest to szczególnie widoczne, jeśli zestawimy dostępne beneficjentom świadczenia dotyczące wspierania bioróżnorodności w ramach PROW 2014-2020, ze świadczeniami w zakresie płatności bezpośrednich, np. wspieraniem zalesiania, płatnościami za zazielenianie oraz regulacjami konserwatorskimi objętymi ustawą o ochronie przyrody, czy też regulacjami dotyczącymi ograniczeń w rozprzestrzenianiu się organizmów GM. Regulacje wpisują się w założenia nowej, globalnej strategii różnorodności biologicznej przyjętej przez strony Konwencji o bioróżnorodności na lata 20112020 (z wizją do roku 2050). Założenia te zostały opracowane i przyjęte podczas 
obrad X Posiedzenia Stron Konferencji, które miało miejsce w Japonii i objęły pięć głównych celów:

- Zlikwidowanie przyczyn utraty bioróżnorodności poprzez włączenie działań na rzecz ochrony przyrody w programy rozwoju gospodarki kraju we wszystkich sektorach, tak na szczeblu rządowym, jak i na poziomie społeczeństwa.

- Ograniczenie bezpośrednich presji na bioróżnorodność oraz promowanie trwałego i zrównoważonego użytkowania.

- Poprawa stanu ochrony bioróżnorodności poprzez zachowanie różnorodności genetycznej na poziomie genów, gatunków i ekosystemów.

- Zwiększenie możliwości powszechnego wykorzystania pożytków wynikających z bioróżnorodności oraz funkcji, jakie spełniają ekosystemy.

- Poprawa możliwości wprowadzania w życie zapisów Konwencji poprzez wdrażanie procesów planowania $\mathrm{z}$ udziałem różnych partnerów, odpowiednie zarządzanie wynikami badań naukowych i wzmocnienie potencjału instytucjonalnego.

Choć nie wydaje się, by realnym było osiągnięcie wszystkich zakładanych celów w perspektywie roku 2020, to jednak uregulowania PROW na lata 2014-2020 należy przyjmować jako zmierzające we właściwym kierunku. 
THE ISSUE OF BIODIVERSITY IN THE NEW RURAL DEVELOPMENT PROGRAMME (RDP) FOR THE YEARS 2014-2020

Key words: biodiversity, protection of biodiversity, the Convention on biodiversity protection, the rural development.

One of the human expansions on Earth there is substantial increase of species extinction rate. And this process leads to significant reduction in biodiversity. However, its protection is necessary for the most elementary reasons:

- to maintain mechanisms of living nature action,

- to maintain nature's capacity to survive the environment changes;

- to prevent the loss of natural values, not yet identified and used, which may constitute the basis for development and guarantee for survival of future generations.

The notion of biodiversity was defined by the Convention on biodiversity adopted at the United Nations Conference on the Environment and Development (so called "Earth Summit") in Rio de Janeiro, 5 $5^{\text {th }}$ June 1992. Both the Republic of Poland and the European Union is the Signatory of this Convention. Therefore, the obligations imposed on the Convention signatories shall be reflected both in the national and the European Union legislation.

Undoubtedly, the legal regulations, both of the Community and the national ones concerning support for rural development include solutions purposed to protect biodiversity. It also appears that these solutions intend to approach the coherent system to support biodiversity.

\section{Bibliografia:}

L. Burke, K. Reytar, M. Spalding, A. Perry, Raport „Reefs at Risk Revisted”, Washington DC, 2011.

J. Ciechanowicz-McLean, Ochrona przyrody w prawie międzynarodowym, [w:] J. Ciechanowicz-McLean (red.), Polskie prawo ochrony przyrody, Warszawa 2006.

A. Kalinowska, Konwencja o różnorodności biologicznej, „Środowisko” 2010, nr 12 (420).

S. Kozłowski, Przyszłość ekorozwoju, Lublin 2007.

Millennium Ecosystem Assessment, 2005. Ecosystems and Human Well-being: Synthesis., Washington, DC.

N. S. Sodhi, P. Ehrlich, Conservation biology for all, New York 2010.

M. Soule, G. Orians, Conservation biology. Research priorities for the next decade, society for conservation biology, Washington 2001. 